\title{
Thermostable RNase P RNAs lacking P18 identified in the Aquificales
}

\author{
MICHAL MARSZALKOWSKI, ${ }^{1}$ JAN-HENDRIK TEUNE, ${ }^{2}$ GERHARD STEGER, ${ }^{2}$ ROLAND K. HARTMANN, ${ }^{1}$ \\ and DAGMAR K. WILLKOMM ${ }^{1}$ \\ ${ }^{1}$ Philipps-Universität Marburg, Institut für Pharmazeutische Chemie, D-35037 Marburg, Germany \\ ${ }^{2}$ Heinrich-Heine-Universität Düsseldorf, Institut für Physikalische Biologie, D-40225 Düsseldorf, Germany
}

\begin{abstract}
The RNase P RNA (rnpB) and protein ( $r n p A)$ genes were identified in the two Aquificales Sulfurihydrogenibium azorense and Persephonella marina. In contrast, neither of the two genes has been found in the sequenced genome of their close relative, Aquifex aeolicus. As in most bacteria, the $r n p A$ genes of $S$. azorense and $P$. marina are preceded by the $r p m H$ gene coding for ribosomal protein L34. This genetic region, including several genes up- and downstream of $r p m H$, is uniquely conserved among all three Aquificales strains, except that $r n p A$ is missing in $A$. aeolicus. The RNase P RNAs (P RNAs) of $S$. azorense and $P$. marina are active catalysts that can be activated by heterologous bacterial $P$ proteins at low salt. Although the two $P$ RNAs lack helix P18 and thus one of the three major interdomain tertiary contacts, they are more thermostable than Escherichia coli P RNA and require higher temperatures for proper folding. Related to their thermostability, both RNAs include a subset of structural idiosyncrasies in their $\mathrm{S}$ domains, which were recently demonstrated to determine the folding properties of the thermostable S domain of Thermus thermophilus P RNA. Unlike 16S rRNA phylogeny that has placed the Aquificales as the deepest lineage of the bacterial phylogenetic tree, RNase P RNA-based phylogeny groups $S$. azorense and $P$. marina with the green sulfur, cyanobacterial, and $\delta / \varepsilon$ proteobacterial branches.
\end{abstract}

Keywords: Aquificales; Sulfurihydrogenibium azorense; Persephonella marina; RNase P; tRNA processing

\section{INTRODUCTION}

The Aquificales are a group of thermophilic bacteria, with Aquifex aeolicus being the best-known representative. $16 \mathrm{~S}$ rRNA, as well as elongation factors $\mathrm{Tu}$ and $\mathrm{G}$, phylogenies have suggested that Aquifex represents the deepest branch of the bacterial phylogenetic tree (Burggraf et al. 1992; Huber et al. 1992; Bocchetta et al. 2000). However, other phylogenetic approaches analyzing conserved small insertions and deletions in a variety of proteins (Gupta 2000; Griffiths and Gupta 2004) and those based on RNA polymerase $\beta, \beta^{\prime}$, and $\sigma^{70}$ subunits (Gruber and Bryant 1998; Klenk et al. 1999) have favored a close affiliation of Aquifex with the $\delta / \varepsilon$ division of the proteobacteria and the Chlamydia-Cytophaga group.

Although RNase $\mathrm{P}$ is the ubiquitous tRNA $5^{\prime}$-end maturation enzyme found in all kingdoms of life, neither

Reprint requests to: Dagmar K. Willkomm, Philipps-Universität Marburg, Institut für Pharmazeutische Chemie, Marbacher Weg 6, D-35037 Marburg, Germany; e-mail: willkomm@staff.uni-marburg.de; fax: +642128-25854.

Article published online ahead of print. Article and publication date are athttp://www.rnajournal.org/cgi/doi/10.1261/rna.242806. a candidate gene for its RNA $(r n p B)$ nor its protein subunit $(r n p A)$ has been identified in the sequenced genome of A. aeolicus (Deckert et al. 1998; Swanson 2001). Likewise, no RNase P-like activity could be detected in cell lysates of the bacterium (Willkomm et al. 2002), and a recent RNomics approach also failed to reveal an RNase P RNA candidate (Willkomm et al. 2005).

To shed light on tRNA 5 '-end maturation in the Aquificales, we analyzed close relatives of A. aeolicus, namely Sulfurihydrogenibium azorense and Persephonella marina, for which genome sequences had been made accessible by The Institute for Genomic Research (TIGR). Our results demonstrate that the two bacteria harbor a bacterial type A RNase P RNA, although with deviations from the bacterial consensus, the major one is the lack of P18. Despite the absence of the L18-P8 interdomain contact, both RNase P RNAs are more active and stable than Escherichia coli RNase $\mathrm{P}$ at higher temperatures $\left(55^{\circ} \mathrm{C}-65^{\circ} \mathrm{C}\right)$. The RNase $\mathrm{P}$ protein genes (rnpA) of S. azorense and P. marina were identified as well and co-localize with the $r p m H$ gene encoding ribosomal protein L34 as in the majority of bacteria (Hartmann and Hartmann 2003). 


\section{RESULTS AND DISCUSSION}

\section{Identification of $r n p B$ genes in $S$. azorense and $P$. marina}

RNase P RNA (P RNA) genes $(r n p B)$ were identified in the completed but yet unpublished genome sequences of $S$. azorense and P. marina (available at TIGR, www.tigr.org) using the program PatScan as described under Materials and Methods.

\section{P RNA structures and kinetics}

The secondary structures of the P RNAs from $P$. marina and S. azorense are shown in Figure 1. The two P RNAs are highly similar (average pairwise sequence identity $\sim 65 \%$ in a structure-based alignment). Besides a few 1- or 2nucleotide (nt) insertions/deletions, $P$. marina differs from S. azorense by two major expansions, one in $\mathrm{P} 12$ and the other in P16/17 to create the P16.1 element in the P. marina structure. The hallmark of the two Aquificales P RNAs is the absence of helix P18, a structural feature originally identified in the genus Chlorobium (Haas et al. 1994). Deletion of P18 eliminates one of the three tetraloop-helix interactions (L8/P4, L9/P1 L18/P8) that bridge S- and Cdomains (Fig. 1). In both RNAs, helices P1 (16 or 18 bp) and P9 (6 bp) are extended, helix P14 has 10 instead of the usual $9 \mathrm{bp}$, and S. azorense P RNA also lacks the bulged nucleotide close to the base of P14. The apical P12 structures are idiosyncratic, and P. marina P RNA has a small stem-loop (P16.1) inserted between helices P16 and P17.

We analyzed the kinetics of the two P RNAs next to E. coli $\mathrm{P}$ RNA under single turnover conditions $(\mathrm{E}>>\mathrm{S})$ at $0.1 \mathrm{M} \mathrm{Mg}^{2+}, 0.1 \mathrm{M} \mathrm{NH}_{4}^{+}$, and $\mathrm{pH}$ 6.0. $\mathrm{P}$ RNAs were preincubated in assay buffer for $5 \mathrm{~min}$ at $55^{\circ} \mathrm{C}$ and $55 \mathrm{~min}$ at $37^{\circ} \mathrm{C}$ to resolve potential folding traps as observed for the thermostable $\mathrm{P}$ RNA of Thermus thermophilus (R.K. Hartmann, unpubl.). Indeed, this preincubation protocol eliminated compacted conformers of $S$. azorense and P. marina P RNAs, which appeared as fast-migrating bands on native PAA gels (data not shown). In contrast,
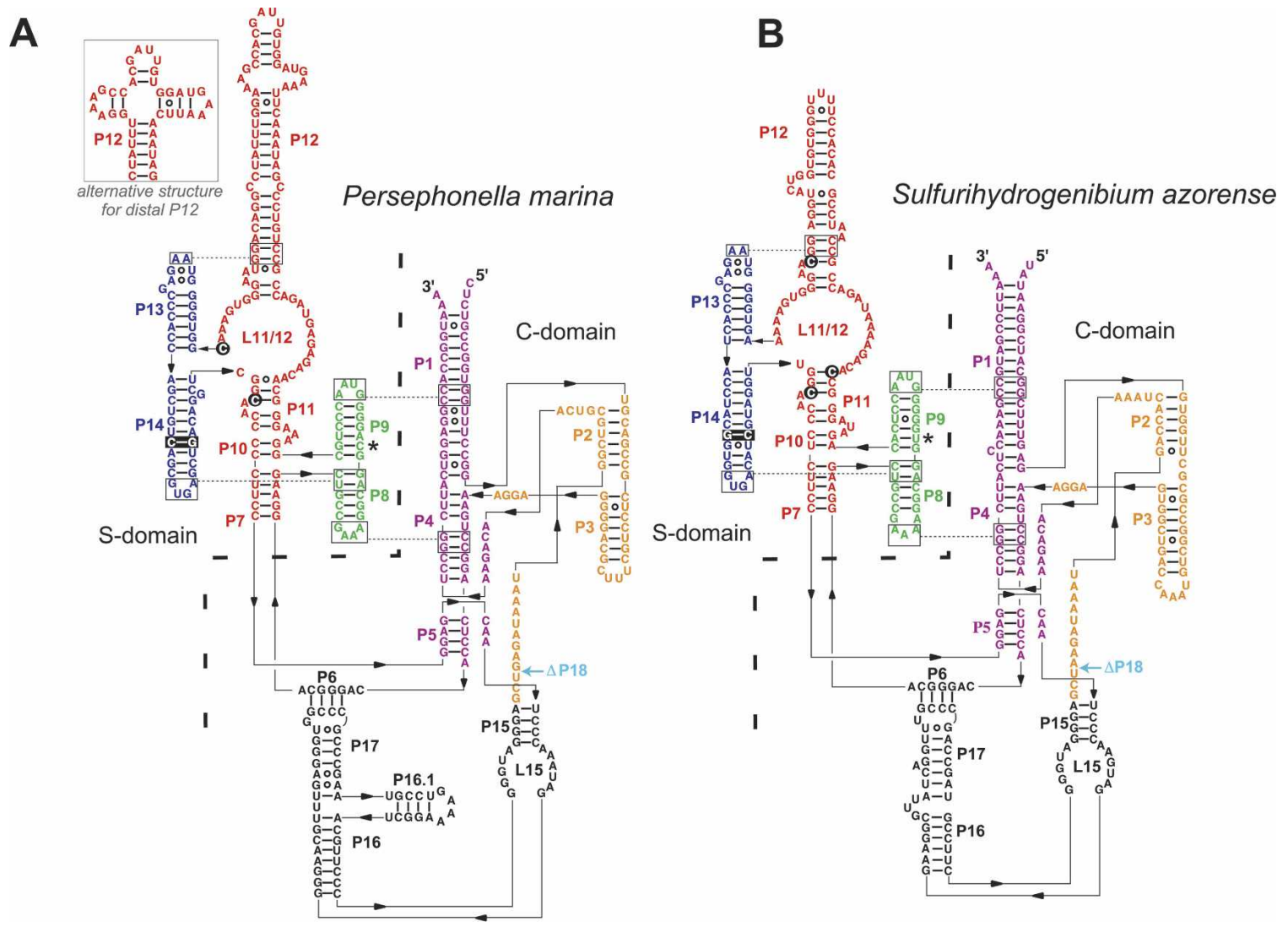

FIGURE 1. Secondary structure presentation of P RNAs from (A) P. marina (accession no. DQ529278) and (B) S. azorense (accession no. DQ529245), according to Tsai et al. (2003) and taking into account the data of Torres-Larios et al. (2005). The C-domain (catalytic domain) and the S-domain (specificity domain) are separated by the broken line. (P) Paired regions; (L) loop regions; (open boxes) tertiary contacts, connected by stippled lines. Highlighted nucleotides and asterisk next to helix P9 mark nucleotide identities and structural features also found in the thermostable S domain of T. thermophilus P RNA (Baird et al. 2006). For the distal part of P12 in the P. marina structure, an alternative cruciform structure is depicted. However, the long P12 stem-loop shown in the main structure contains an internal loop with a stabilizing sarcin-ricin motif in its bulge (5'-AGUA- and 5'-GAA-; Leontis and Westhof 1998; Zhong et al. 2006) and is energetically favored according to thermodynamic calculations (Hofacker 2003). 
preincubation only for $1 \mathrm{~h}$ at $37^{\circ} \mathrm{C}$ incompletely (S. azorense) or completely ( $P$. marina) failed to resolve these conformers. The kinetic results are summarized in Table 1 . At $37^{\circ} \mathrm{C}$ and in comparison with E. coli P RNA, the $S$. azorense ribozyme cleaved the precursor tRNA ${ }^{\text {Gly }}$ (ptRNA ${ }^{\text {Gly }}$ ) substrate with about the same single turnover $K_{\mathrm{m}(\mathrm{sto})}$, but at a three- to fourfold reduced maximum cleavage rate $\left(k_{\text {react }}\right)$. Catalytic performance of $P$. marina $\mathrm{P}$ RNA was lower, with approximately a sevenfold increase in $K_{\mathrm{m}(\mathrm{sto})}$ and a 31 -fold decrease in $k_{\text {react }}$. Since the two Aquificales are thermophilic bacteria (growth optima $\sim 70^{\circ} \mathrm{C}$; Götz et al. 2002; Aguiar et al. 2004), we tested processing activity at two additional temperatures $\left(55^{\circ} \mathrm{C}\right.$ and $\left.65^{\circ} \mathrm{C}\right)$, using $\mathrm{P}$ RNA concentrations $(0.27 \mu \mathrm{M}$ for $E$. coli, $0.27 \mu \mathrm{M}$ for S. azorense, and $2.0 \mu \mathrm{M}$ for $P$. marina) around the respective $K_{\mathrm{m}(\text { sto) }}$ value determined at $37^{\circ} \mathrm{C}$ (see Table 1 ). For this purpose, $\mathrm{P}$ RNAs were preincubated in assay buffer for $1 \mathrm{~h}$ at $55^{\circ} \mathrm{C}$ or $65^{\circ} \mathrm{C}$ before addition of substrate and incubation at the same temperature. Whereas the rate of cleavage $\left(k_{\text {obs }}\right)$ by E. coli P RNA decreased from $4.7 \mathrm{~min}^{-1}$ at $37^{\circ} \mathrm{C}$ to $2.8 \mathrm{~min}^{-1}$ at $55^{\circ} \mathrm{C}$ to $1.3 \mathrm{~min}^{-1}$ at $65^{\circ} \mathrm{C}$, the two Aquificales $\mathrm{P}$ RNAs showed a higher substrate turnover at $55^{\circ} \mathrm{C}$ versus $37^{\circ} \mathrm{C}$ (Table 1 ). In the case of $S$. azorense $\mathrm{P}$ $\mathrm{RNA}$, the cleavage rate at $65^{\circ} \mathrm{C}$ was still equal to that at $37^{\circ} \mathrm{C}$, although substrate affinity is expected to be lower at $65^{\circ} \mathrm{C}$ than $37^{\circ} \mathrm{C}$. Inspection of experimental endpoints (EP, maximum fraction of substrate that could be converted to mature tRNA during extended incubation times) obtained in the individual processing reactions revealed that $\leq 40 \%$ of substrate could be cleaved by E. coli P RNA at $65^{\circ} \mathrm{C}$. In contrast, endpoints remained normal $(>80 \%)$ for reactions catalyzed by the two Aquificales P RNAs (Table 1). These findings suggest that E. coli $\mathrm{P}$ RNA, but not $P$. marina and $S$. azorense $\mathrm{P}$ RNAs, traps a substantial fraction of the substrate in an inactive conformation at $65^{\circ} \mathrm{C}$, which we interpret as an indication of partial un- or misfolding of E. coli P RNA at this temperature.

\section{Holoenzyme activity assays}

The two Aquificales P RNAs, and E. coli P RNA as a control, were reconstituted with the E. coli or Bacillus subtilis $\mathrm{P}$ protein and tested for processing activity in the presence of $2 \mathrm{mM} \mathrm{Mg}^{2+}$ under multiple turnover conditions at $37^{\circ} \mathrm{C}$ (Table 1). In general, bacterial P RNAs do not show RNAalone activity under these conditions. Both Aquificales $\mathrm{P}$ RNAs could be activated by the two heterologous $\mathrm{P}$ proteins, S. azorense P RNA more efficiently than P. marina P RNA, and both much less efficiently than E. coli P RNA. Since the conformation of the $P$. marina P RNA was not uniform at $2 \mathrm{mM} \mathrm{Mg}^{2+}$, as inferred from native PAGE (data not shown), we measured the activity of the reconstituted holoenzymes at $10 \mathrm{mM} \mathrm{Mg}^{2+}$, with the $\mathrm{pH}$ lowered to 6.5 to suppress RNA-alone cleavage. Under these conditions, all P RNAs were homogeneously folded according to native PAGE analyses (data not shown), and RNA-alone

TABLE 1. Kinetic data for reactions catalyzed by P RNA alone and hybrid holoenzymes

\begin{tabular}{|c|c|c|c|c|c|c|c|c|}
\hline \multirow[b]{2}{*}{ P RNA } & \multicolumn{4}{|c|}{$37^{\circ} \mathrm{C}$} & \multicolumn{2}{|c|}{$55^{\circ} \mathrm{C}$} & \multicolumn{2}{|c|}{$65^{\circ} \mathrm{C}$} \\
\hline & $K_{\mathrm{m}(\mathrm{sto})}(\mu \mathrm{M})$ & $k_{\text {react }}\left(\min ^{-1}\right)$ & $k_{\text {obs }}\left(\min ^{-1}\right)$ & EP & $k_{\text {obs }}\left(\min ^{-1}\right)$ & EP & $k_{\text {obs }}\left(\min ^{-1}\right)$ & EP \\
\hline E. coli & $0.24( \pm 0.03)$ & $9.7( \pm 0.6)$ & $4.7( \pm 0.3)$ & 0.92 & $2.8( \pm 0.25)$ & 0.8 & $1.3( \pm 0.4)$ & 0.4 \\
\hline S. azorense & $0.28( \pm 0.05)$ & $2.7( \pm 0.2)$ & $1.4( \pm 0.1)$ & 0.9 & $3.1( \pm 0.4)$ & 0.93 & $1.25( \pm 0.2)$ & 0.85 \\
\hline P. marina & $1.97( \pm 0.39)$ & $0.32( \pm 0.02)$ & $0.15( \pm 0.01)$ & 0.76 & $0.6( \pm 0.01)$ & 0.92 & $0.06( \pm 0.01)$ & 0.9 \\
\hline \multicolumn{2}{|c|}{ Holoenzymes } & \multicolumn{2}{|c|}{$k_{\text {obs }}\left(\min ^{-1}\right)$} & & & & & \\
\hline P RNA & + Protein & $2 \mathrm{mM} \mathrm{Mg}^{2+}$ & $10 \mathrm{mM} \mathrm{Mg}^{2+}$ & & & & & \\
\hline \multirow[t]{2}{*}{ E. coli } & E. coli & $3.5( \pm 0.3)$ & $4.8( \pm 0.58)$ & & & & & \\
\hline & B. subtilis & $4.2( \pm 0.2)$ & $4.8( \pm 1.1)$ & & & & & \\
\hline \multirow[t]{2}{*}{ S. azorense } & E. coli & $0.05( \pm 0.003)$ & $0.43( \pm 0.05)$ & & & & & \\
\hline & B. subtilis & $0.24( \pm 0.06)$ & $0.47( \pm 0.04)$ & & & & & \\
\hline \multirow[t]{2}{*}{ P. marina } & E. coli & $0.028( \pm 0.003)$ & $0.56( \pm 0.16)$ & & & & & \\
\hline & B. subtilis & $0.014( \pm 0.001)$ & $0.70( \pm 0.12)$ & & & & & \\
\hline
\end{tabular}

RNA-alone reactions were performed under single-turnover conditions $(\mathrm{E} \gg \mathrm{S})$ using trace amounts $(<1 \mathrm{nM})$ of $5^{\prime}$-end labeled T. thermophilus ptRNA ${ }^{\text {Gly }}$ as substrate in a reaction buffer containing $100 \mathrm{mM} \mathrm{Mg}(\mathrm{OAc})_{2}, 100 \mathrm{mM} \mathrm{NH}_{4} \mathrm{OAc}, 0.1 \mathrm{mM}$ EDTA, $50 \mathrm{mM} \mathrm{MES} \mathrm{pH} 6.0$ at the indicated temperatures; processing reactions were started by combining enzyme and substrate solutions; $K_{\mathrm{m}(\mathrm{sto})}$ and $K_{\text {react }}$ are the single turnover $K_{\mathrm{m}}$ and $v_{\max }$ values, $k_{\mathrm{obs}}$ values designate the cleavage rate at a single P RNA concentration $(0.27 \mathrm{mM}$ for $E$. coli, $0.27 \mathrm{mM}$ for $S$. azorense, and $2.0 \mathrm{mM}$ for $P$. marina RNase P RNA), and EP is the experimental endpoint (maximum fraction of substrate that could be converted to mature tRNA during extended incubation times). Assay conditions for holoenzyme reactions, performed under multiple turnover conditions: $150 \mathrm{mM}$ $\mathrm{NH}_{4} \mathrm{OAc}, 2 \mathrm{mM}$ spermidine, $0.05 \mathrm{mM}$ spermine, $4 \mathrm{mM} \beta$-mercaptoethanol, $10 \mathrm{nM} \mathrm{P}$ RNA, $40 \mathrm{nM}$ P protein, and $100 \mathrm{nM}$ ptRNA ${ }^{\mathrm{Gly}}, 2$ or $10 \mathrm{mM} \mathrm{Mg}(\mathrm{OAc})_{2}, 20 \mathrm{mM}$ Hepes $\mathrm{pH} 7.4\left(37^{\circ} \mathrm{C}\right)$ with $2 \mathrm{mM} \mathrm{Mg}^{2+}$, and $\mathrm{pH} 6.5$ with $10 \mathrm{mM} \mathrm{Mg}^{2+}$; under holoenzyme conditions, no RNA-alone activity was observed in the time window of the assay, except for $E$. coli RNA alone at $10 \mathrm{mM} \mathrm{Mg}^{2+}\left(k_{\mathrm{obs}}=0.14 \mathrm{~min}^{-1}\right)$. In the holoenzyme reactions, $k_{\mathrm{obs}}$ is given as nanomoles of substrate converted per nanomole of RNase P RNA per minute. All values are based on at least three independent experiments. For more details, see Materials and Methods. 
activity was low for the E. coli and not detectable for the P. marina and S. azorense P RNAs. At $10 \mathrm{mM} \mathrm{Mg}^{2+}$, the activity of holoenzymes containing the Aquificales P RNAs increased relative to those with $E$. coli $\mathrm{P}$ RNA, and activity profiles for the two Aquificales P RNAs were now reversed, the chimeric $P$. marina holoenzymes being more active than the $S$. azorense counterparts. Our results illustrate that the $\mathrm{Mg}^{2+}$ requirements for folding and catalysis of the three $\mathrm{P}$ RNAs differ markedly, being highest for $P$. marina and higher for the Aquificales than for E. coli P RNA. We additionally tested if the $P$. marina and $S$. azorense $\operatorname{rnp} B$ genes might be able to replace the native $\operatorname{rnp} B$ gene in the $B$. subtilis mutant strain SSB318 (Wegscheid et al. 2006), but the results were negative (data not shown). Altogether, these results support the notion that the two Aquificales strains encode a canonical bacterial type A RNase P holoenzyme, however, with idiosyncratic features.

\section{Identification of rnpA genes}

The rnpA genes encoding the protein subunit of RNase $\mathrm{P}$ in $P$. marina and $S$. azorense were identified (Fig. 2A) by using a local version of tblastn (see Materials and Methods). Both rnpA genes are sandwiched between the $r p m H$ gene encoding ribosomal protein L34 and the downstream yidD-YidC genes (Fig. 2B), which represent the genetic context found in most bacteria (Hartmann and Hartmann 2003). In the case of S. azorense $\operatorname{rnpA}$, the only candidate start codon is a CUG immediately upstream of the rpmH stop codon (data not shown); CUG has been described as a low-efficiency start codon (O'Donnell and Janssen 2001). We also considered the possibility of a sequencing error in an $A_{9}$ stretch at the beginning of $S$. azorense rnpA (nucleotides 19-27 of rnpA, accession no. DQ529246). We thus sequenced a PCR fragment derived from $S$. azorense genomic DNA. However, the sequence as provided by TIGR turned out to be correct. An alignment with other bacterial $\mathrm{P}$ proteins (Fig. 2A) supported our annotation of rmpA genes.

\section{Thermostability of Aquificales P RNAs}

Thermostability of $P$. marina and $S$. azorense $\mathrm{P}$ RNAs despite the absence of P18 is a surprising finding of this study. The apical loop of P18 docks to P8 as one of the three major tertiary interactions (L8/P4, L18/P8, L9/P1) that bridge S- and C-domains (Fig. 1) in bacterial type A RNAs. The only other known bacterial P RNAs lacking P18 are from mesophilic Chlorobia (Haas et al. 1994), where RNA stability is expected to be less crucial than in thermophiles. Deletion of P18 from E. coli P RNA caused a 60-fold increase in $K_{\mathrm{m}}$ under multiple turnover conditions at $25 \mathrm{mM} \mathrm{Mg}^{2+}$ and $1 \mathrm{M} \mathrm{NH}_{4}{ }^{+}$(Haas et al. 1994). The absence of the L18/P8 contact in the two Aquificales P RNAs may be compensated by strengthening the L9/P1 contact. Evidence for this possibility stems from the observation that helices P1 can be extended to 16 and $18 \mathrm{bp}$, respectively (Fig. 1), and P9 to $6 \mathrm{bp}$ in both RNAs. Mesophilic P RNAs usually have 11 bp in P1 and 4-5 bp in P9, including a bulged nucleotide near the base of the stem in P1 as well as P9, which interrupts helix continuity (Massire et al. 1998; Fig. 3). Helix P9 is also stabilized in other thermostable $\mathrm{P}$ RNAs ( 5 bp and deletion of the bulge in Thermotoga maritima, and 5 G-C bp in T. thermophilus), as is $\mathrm{P} 1$ (12-14 bp in $T$. thermophilus and T. aquaticus, absence of the nucleotide bulge in P1 of T. maritima) (Massire et al. 1998; Fig. 3). Furthermore, the two Aquificales and

FIGURE 2. (A) Alignment of S. azorense and P. marina P protein sequences (accession nos. DQ529246 and DQ529279) with those of selected bacteria. (Red) Amino acid or type of amino acid conserved in all five sequences; (blue) conserved in at least three of the five sequences; (!)I or V; (\#)D, E, N, or Q. Secondary structure elements are shown for the T. maritima P protein (Kazantsev et al. 2003). (B) Schematic illustration of the $r p m H / r n p A$ gene context in the three Aquificales strains relative to $T$. maritima representing the mainstream of bacteria; accession nos. for the genomic regions of S. azorense and P. marina: DQ529246 and DQ529279. 


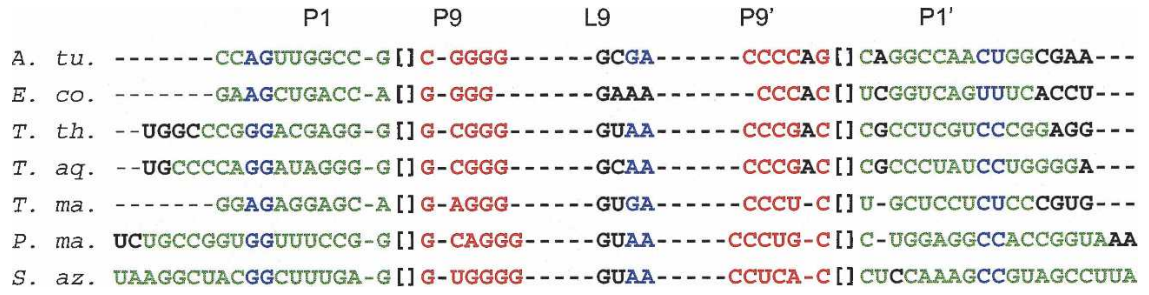

FIGURE 3. Partial alignment of P1, P9, and L9 sequences (P1 and P9 designate the $5^{\prime}$ halves and $\mathrm{P}^{\prime}$ and $\mathrm{P9}^{\prime}$ the $3^{\prime}$ halves of the respective helix), according to Massire et al. (1998). (Blue) Nucleotides that take part in the tetraloop-helix interaction; (green) canonical pairings, including G-U pairs, within P1; (red) canonical pairings, including G-U pairs, within P9; (black) unpaired nucleotides, and all L9 nucleotides in E. coli RNase P RNA, as the geometry of this tertiary contact is unclear (Massire et al. 1998). RNase P RNAs from the two Thermus and the two Aquificales species are the only known examples of apical L9 5'-GYAA tetraloops interacting with two consecutive G-C bp in P1. (A. tu.) Agrobacterium tumefaciens, (E. co.) E. coli, (T. th.) T. thermophilus, (T. aq.) T. aquaticus, (T. ma.) T. maritima, (P. ma.) P. marina, (S. az.) S. azorense.

context of $r m p B$ genes in S. azorense and $P$. marina, hoping that a conserved context may guide us to a so far unidentified rnpB gene in $A$. aeolicus. However, the context of $r n p B$ already deviates entirely between $S$. azorense and $P$. marina (data not shown).

A number of phylogenies, in particular the one based on 16S rRNA, have positioned Aquifex and the Aquificales as the deepest branch of the bacterial phylogenetic tree (Burggraf et al. 1992; Huber et al. 1992; Bocchetta et al. 2000). Phylogenetic trees on the basis of RNase P RNA, which we constructed from a structure-based sequence alignment (Massire et al. 1998) using the

Thermus $\mathrm{P}$ RNAs share the feature of a 5'-GYAA L9 tetraloop and a P1 receptor site consisting of a G-C bp tandem, a combination not present in other bacteria (Massire et al. 1998; Fig. 3). Increased stiffness of P9 and its $\mathrm{P} 1$ receptor region in $P$. marina, S. azorense, and Thermus may stabilize the L9/P1 interaction, which in turn may partially compensate for the absence of the L18/P8 contact in the two Aquificales RNAs.

Tao Pan and coworkers have introduced 12 key base identities of the T. thermophilus $\mathrm{S}$ domain into that of E. coli (Baird et al. 2006). The E. coli S-domain mutant gained the same stability and $\mathrm{Mg}^{2+}$-dependent folding cooperativity as the T. thermophilus S domain. Subsets of these T. thermophilus features are present in the two Aquificales P RNAs (Fig. 1, highlighted nucleotides, asterisk next to P9). This includes, for example, the stabilization of P9, P11, and P14 (for details, see Baird et al. 2006). These structural similarities to $T$. thermophilus P RNA may contribute as well to thermostability of the two Aquificales P RNAs.

\section{Phylogenetic aspects}

So far, no candidate genes for the RNA $(r n p B)$ or the protein subunit $(r n p A)$ have been identified in the sequenced genome of A. aeolicus (Deckert et al. 1998; Swanson 2001). However, in S. azorense and P. marina, rnpA is encoded with $r p m H$, as in the majority of bacteria. Surprisingly, the genetic context of rpmH genes in A. aeolicus, S. azorense, and $P$. marina is very similar except for the absence of $r n p A$ in A. aeolicus. This not only holds for yidD and yidC downstream of $r p m H / r n p A$, a conserved trait in most bacteria, but also for the $r p m H$ upstream region (Fig. 2B). Here, all three Aquificales encode a conserved hypothetical protein (aq_178 in A. aeolicus) and an ATP synthase subunit, a constellation not observed outside the Aquificales (Hartmann and Hartmann 2003). Thus, the apparent loss of genes for bacterial-like RNase P components is confined to the genus Aquifex or the Aquificaceae. We further inspected the genetic program fastDNAml, unexpectedly did not corroborate an early origin of the Aquificales P RNAs (data not shown). With substantial variation in detail caused by small changes in the alignment, the $\mathrm{P}$ RNA trees all grouped the Aquificales with the green sulfur, cyanobacterial, and $\delta$ or $\varepsilon$ proteobacterial branches, in general agreement with several protein-based phylogenies (Gruber and Bryant 1998; Klenk et al. 1999; Gupta 2000; Griffiths and Gupta 2004). The lack of P18 in the P. marina and S. azorense P RNAs, a feature they share with Archaea and Eukaryotes, thus seems to represent not an ancient, but a derived, trait.

\section{MATERIALS AND METHODS}

\section{Bioinformatic analyses}

Genes encoding RNase P RNA $(r n p B)$ were identified in the completed but yet unpublished genome sequences of $S$. azorense and P. marina (available at TIGR, www.tigr.org) using PatScan (Dsouza et al. 1997). The pattern to describe the RNase P RNAencoding genes consisted of several conserved sequence and structure-based pattern units. There are two main conserved sequence elements in the core structure: 5'-GAGGAANNUCNNNNC (designated as CR I) (Chen and Pace 1997) and 5'-AGNNNNAU...\{2-67 nt ...ACANAA (designated as CR IV) (Chen and Pace 1997). These conserved sequence elements were surrounded by additional conserved structural elements to reduce the amount of false-positive hits. The pattern description was ("/" stands for line break):

\section{\%RNaseP Pattern description File}

$\mathrm{r} 1=\{\mathrm{au}, \mathrm{ua}, \mathrm{gc}, \mathrm{cg}, \mathrm{gu}, \mathrm{ug}\} / \mathrm{p} 2=6 \ldots 7 /(\mathrm{G} \mid 3 \ldots 4) / \mathrm{p} 3=1 \ldots 6 / 3 \ldots 72 /$

$\mathrm{r} 1 \sim \mathrm{p} 3[1,0,0] / \mathrm{GAGGA} / \mathrm{p} 4=\mathrm{ANN} / \mathrm{U} / \mathrm{p} 6=\mathrm{CNNNN} / \mathrm{C} / \mathrm{p} 5=3 \ldots 4$

$/ 1 \ldots 27 / \mathrm{p} 7=3 \ldots 7 / 50 \ldots 300 / \mathrm{r} 1 \sim \mathrm{p} 7[1,0,0] / \mathrm{r} 1 \sim \mathrm{p} 5[1,0,0] / \mathrm{NAA} /$

$\mathrm{p} 15=2 \ldots 4 / 4 \ldots 95 / \mathrm{r} 1 \sim \mathrm{p} 15 / \mathrm{G} / 2 \ldots 67 / \mathrm{AGNNNNAU} / \mathrm{r} 1 \sim \mathrm{p} 2$

$[1,0,0] / 2 \ldots 60 /$ ACANAA $/ \mathrm{r} 1 \sim \mathrm{p} 6[1,0,0] / \mathrm{r} 1 \sim \mathrm{p} 4[1,0,0] / \mathrm{A}$ 
For calculation of phylogenetic trees, we structurally aligned the RNase P RNA sequences of P. marina and S. azorense and-as outgroups-Homo sapiens and Thermococcus litoralis or Sulfolobus acidocaldarius to the structural alignment of bacterial RNase P RNA sequences from Massire et al. (1998), using ConStruct (Luck et al. 1999) and making manual adjustments. After removal of all partial sequences (e.g., those lacking P1), phylogenetic trees were predicted using fastDNAml (Felsenstein 1981; Olsen et al. 1994).

The rnpA genes encoding the protein subunit of bacterial RNase $\mathrm{P}$ were identified by using a local version of tblastn, which is part of the BLAST package (Altschul et al. 1990). The RNase P protein sequence from E. coli (Acc. AAC76727) was used as a query to search for potential rnpA coding regions in the provided genomes. Finally, the resulting sequence(s) were used to query the NCBI BLAST servers for validation.

Secondary structure predictions were performed using Mfold (Zuker 2003). ClustalW (www.ebi.ac.uk/clustalw) was used for nucleic acid sequence alignments, and protein sequences were aligned with MultAlin (Corpet 1988).

\section{Cloning of RNase P RNA candidates}

For the construction of plasmids pUC19T7Pma_rnpB and pUC19T7Saz_rnpB, to be used as templates for in vitro transcription of the two P RNAs, respective DNA sequences were amplified by genomic PCR using primers 5 '-GCGGGATCCTAATACGACT CACTATAGGATATCTCTGCCGGTGGTTTCC-3' and 5'-CGC CTTAAGACCGGTGGCCTCCAGTAA-3' for P. marina, and $5^{\prime}$ GCGGGATCCTAATACGACTCACTATAGGTATAAGGCTACG GCTTTGAG-3' and 5'-CGCCTTAAGTTTAAGGCTACGGCTT TGGAG-3' for $S$. azorense. PCR fragments were cloned into pUC19 via EcoRI and BamHI sites included in the primers (underlined); the sense primers additionally introduced a T7 promoter (in italics).

\section{In vitro transcription and $\mathbf{5}^{\prime}$-end labeling}

RNAs were produced by run-off transcription with T7 RNA polymerase and subsequent gel purification as described in Busch et al. (2000). The substrate, T. thermophilus ptRNA ${ }^{\mathrm{Gly}}$, was transcribed from plasmid pSBpt3'HH (Busch et al. 2000), and E. coli P RNA from plasmid pDW98 (Smith et al. 1992) linearized with BsaAI. S. azorense and P. marina P RNAs were transcribed from plasmids pUC19T7Saz_rnpB and pUC19T7Pma_rnpB, both linearized with EcoRI, resulting in 20 and 17 extra nucleotides, respectively, beyond the $3^{\prime}$ ends shown in Figure 1. Substrate $5^{\prime}$-end labeling with $\left[\gamma^{-}{ }^{32} \mathrm{P}\right]$-ATP and T4 polynucleotide kinase was performed as detailed in Heide et al. (1999).

\section{Sequencing of PCR products and recombinant plasmids}

DNA sequencing was performed by MWG-BIOTECH AG (Ebersberg, Germany).

\section{Preparation of recombinant RNase $\mathbf{P}$ proteins}

E. coli and B. subtilis RNase $\mathrm{P}$ proteins carrying an $\mathrm{N}$-terminal His-tag (His-tagged peptide leader: MRGSHHHHHHGS, encoded in plasmid pQE-30 in E. coli JM109) were expressed essentially as described (Rivera-León et al. 1995). Cell cultures were grown in LB broth containing $100 \mu \mathrm{g} / \mathrm{mL}$ ampicillin to an $\mathrm{OD}_{600}$ of 0.6 , and IPTG was added to a final concentration of $1 \mathrm{mM}$. Cells were harvested at $4^{\circ} \mathrm{C}$ after another $3 \mathrm{~h}$ of growth $\left(\mathrm{OD}_{600} \sim 2.5\right)$. The following steps were performed at $4^{\circ} \mathrm{C}$ or on ice, and all buffers contained $40 \mu \mathrm{g} / \mathrm{mL}$ of the protease inhibitor phenylmethylsulfonyl fluoride (PMSF). Cells were suspended in 10-15 mL sonication buffer SB (50 mM Tris- $\mathrm{HCl}, \mathrm{pH} 8.0,0.3 \mathrm{M} \mathrm{NaCl}$, $0.1 \%$ triton $\mathrm{X}-100,1 \mathrm{M} \mathrm{NH} \mathrm{N}_{4} \mathrm{Cl}$ ). After sonication (Branson Sonifier 250 , output 20 , duty cycle $50 \%, 15 \mathrm{~min}$ on ice), the sample was centrifuged for $30 \mathrm{~min}\left(4^{\circ} \mathrm{C}, 14,500 \mathrm{~g}\right)$, and the supernatant was mixed with Ni-NTA agarose $(400 \mu \mathrm{L}$ for $2 \mathrm{~L}$ of cell culture), which had been prewashed twice with $10 \mathrm{~mL} \mathrm{SB}$ buffer. The sample was then incubated for $1-2 \mathrm{~h}$ at $4^{\circ} \mathrm{C}$ under gentle mixing or rotating. The Ni-NTA agarose slurry was washed three times (centrifugation-resuspension cycles; centrifugation at $4^{\circ} \mathrm{C}$ and $8500 \mathrm{rpm}$ in a desktop centrifuge) with ice-cold washing buffer (30 mM imidazol, $50 \mathrm{mM}$ Tris- $\mathrm{HCl}, \mathrm{pH}$ 8.0, $8 \mathrm{M}$ urea, $0.1 \%$ triton $\mathrm{X}-100)$. Proteins were then eluted with $500 \mu \mathrm{L}$ elution buffer (50 mM Tris- $\mathrm{HCl}$, pH 7.0, 10\% glycerol, $7 \mathrm{M}$ urea, $20 \mathrm{mM}$ EDTA, $0.3 \mathrm{M}$ imidazol) for $45 \mathrm{~min}$ at $4^{\circ} \mathrm{C}$ under gentle shaking. Eluates were dialyzed twice for $1 \mathrm{~h}$ and subsequently overnight against volumes of $500 \mathrm{~mL}$ dialysis buffer $(50 \mathrm{mM}$ Tris- $\mathrm{HCl}, \mathrm{pH}$ 7.0, $0.1 \mathrm{M} \mathrm{NaCl}, 10 \%$ glycerol, dialysis bags: Roth, molecular weight cut-off $12-14 \mathrm{kDa}$ ); during dialysis, a white precipitate formed. The contents of the dialysis tubes were transferred to a 2 $\mathrm{mL}$ Eppendorf tube and centrifuged for $20 \mathrm{~min}$ at $4^{\circ} \mathrm{C}$ and 12,000 $\mathrm{rpm}$ in a desktop centrifuge. The supernatant contained RNase $\mathrm{P}$ protein devoid of any P RNA contamination, whereas the pellet included traces of P RNA and was therefore discarded. All purification steps were monitored by $17 \%$ SDS-PAGE to assess the purity and concentration of RNase P proteins.

\section{Kinetics}

For single-turnover RNA-alone reactions, trace amounts $(<1 \mathrm{nM})$ of 5 '-end labeled $T$. thermophilus ptRNA ${ }^{\text {Gly }}$ substrate were preincubated in reaction buffer $\left(100 \mathrm{mM} \mathrm{Mg}[\mathrm{OAc}]_{2}, 100 \mathrm{mM}\right.$ $\mathrm{NH}_{4} \mathrm{OAc}, 0.1 \mathrm{mM}$ EDTA, $50 \mathrm{mM}$ MES pH $\left.6.0\left[37^{\circ}\right]\right)$ for $5 \mathrm{~min}$ at $55^{\circ} \mathrm{C}$ and $25 \mathrm{~min}$ at $37^{\circ} \mathrm{C}$. Likewise, P RNAs were preincubated in the same buffer for $5 \mathrm{~min}$ at $55^{\circ} \mathrm{C}$ and $55 \mathrm{~min}$ at $37^{\circ} \mathrm{C}$. Processing reactions were started by combining enzyme and substrate solutions and assayed at $37^{\circ} \mathrm{C}$. For processing assays at $55^{\circ} \mathrm{C}$ and $65^{\circ} \mathrm{C}, \mathrm{P}$ RNA solutions were preincubated for $1 \mathrm{~h}$ at $55^{\circ} \mathrm{C}$ or $65^{\circ} \mathrm{C}$.

For holoenzyme cleavage assays, buffer $\mathrm{KN}$ (20 mM Hepes$\mathrm{KOH}, \mathrm{pH} 7.4,2 \mathrm{mM} \mathrm{Mg}[\mathrm{OAc}]_{2}, 150 \mathrm{mM} \mathrm{NH} \mathrm{NHAc}_{4} \mathrm{O} 2 \mathrm{mM}$ spermidine, $0.05 \mathrm{mM}$ spermine, and $4 \mathrm{mM} \beta$-mercaptoethanol) (Dinos et al. 2004) was used to closely mimic physiological conditions. In addition, these assays were performed in the identical buffer, but at $\mathrm{pH} 6.5$ and $10 \mathrm{mM} \mathrm{Mg}[\mathrm{OAc}]_{2}$. In vitro reconstitution of RNase $\mathrm{P}$ holoenzymes was performed as follows: RNase P RNAs were incubated in buffer $\mathrm{KN}$ for $5 \mathrm{~min}$ at $55^{\circ} \mathrm{C}$ and $50 \mathrm{~min}$ at $37^{\circ} \mathrm{C}$, after which RNase P protein was added, followed by another $5 \mathrm{~min}$ at $37^{\circ} \mathrm{C}$ before addition of substrate. Aliquots of the cleavage reactions were withdrawn at various time points and analyzed by electrophoresis on $20 \%$ polyacrylamide/ $8 \mathrm{M}$ urea gels. Data analysis and calculations were performed essentially as previously described (Busch et al. 2000). 


\section{ACKNOWLEDGMENTS}

We thank the Deutsche Forschungsgemeinschaft for financial support (DFG HA1672/13-1) and the Wilhelm-Hahn-undErben-Stiftung for defraying publication charges. We also thank Anna-Louise Reysenbach (Portland, Oregon, USA) for the gift of $S$. azorense and $P$. marina genomic DNA, TIGR for making genomic sequences of the two organisms available before publication, and the reviewers for insightful comments.

Received July 28, 2006; accepted August 26, 2006.

\section{REFERENCES}

Aguiar, P., Beveridge, T.J., and Reysenbach, A.L. 2004. Sulfurihydrogenibium azorense, sp. nov., a thermophilic hydrogen-oxidizing microaerophile from terrestrial hot springs in the Azores. Int. J. Syst. Evol. Microbiol. 54: 33-39.

Altschul, S., Gish, W., Miller, W., Myers, E., and Lipman, D. 1990. A basic local alignment search tool. J. Mol. Biol. 215: 403-410.

Baird, N.J., Srividya, N., Krasilnikov, A.S., Mondragon, A., Sosnick, T.R., and Pan, T. 2006. Structural basis for altering the stability of homologous RNAs from a mesophilic and a thermophilic bacterium. RNA 12: 598-606.

Bocchetta, M., Gribaldo, S., Sanangelantoni, A., and Cammarano, P. 2000. Phylogenetic depth of the bacterial genera Aquifex and Thermotoga inferred from analysis of ribosomal protein, elongation factor, and RNA polymerase subunit sequences. J. Mol. Evol. 50: 366-380.

Burggraf, S., Olsen, G.J., Stetter, K.O., and Woese, C.R. 1992. A phylogenetic analysis of Aquifex pyrophilus. Syst. Appl. Microbiol. 15: 352-356.

Busch, S., Kirsebom, L.A., Notbohm, H., and Hartmann, R.K. 2000. Differential role of the intermolecular base-pairs G292-C(75) and G293-C(74) in the reaction catalyzed by Escherichia coli RNase P RNA. J. Mol. Biol. 299: 941-951.

Chen, J.L. and Pace, N.R. 1997. Identification of the universally conserved core of ribonuclease P RNA. RNA 3: 557-560.

Corpet, F. 1988. Multiple sequence alignment with hierarchical clustering. Nucleic Acids Res. 16: 10881-10890.

Deckert, G., Warren, P.V., Gaasterland, T., Young, W.G., Lenox, A.L., Graham, D.E., Overbeek, R., Snead, M.A., Keller, M., Aujay, M., et al. 1998. The complete genome of the hyperthermophilic bacterium Aquifex aeolicus. Nature 392: 353-358.

Dinos, G., Wilson, D.N., Teraoka, Y., Szaflarski, W., Fucini, P., Kalpaxis, D., and Nierhaus, K.H. 2004. Dissecting the ribosomal inhibition mechanisms of edeine and pactamycin: The universally conserved residues G693 and C795 regulate P-site RNA binding. Mol. Cell 13: 113-124.

Dsouza, M., Larsen, N., and Overbeek, R. 1997. Searching for patterns in genomic data. Trends Genet. 13: 497-498.

Felsenstein, J. 1981. Evolutionary trees from DNA sequences: A maximum likelihood approach. J. Mol. Evol. 17: 368-376.

Götz, D., Banta, A., Beveridge, T.J., Rushdi, A.I., Simoneit, B.R., and Reysenbach, A.L. 2002. Persephonella marina gen. nov., sp. nov. and Persephonella guaymasensis sp. nov., two novel, thermophilic, hydrogen-oxidizing microaerophiles from deep-sea hydrothermal vents. Int. J. Syst. Evol. Microbiol. 52: 1349-1359.

Griffiths, E. and Gupta, R.S. 2004. Signature sequences in diverse proteins provide evidence for the late divergence of the order Aquificales. Int. Microbiol. 7: 41-52.

Gruber, T.M. and Bryant, D.A. 1998. Characterization of the group 1 and group $2 \sigma$ factors of the green sulfur bacterium Chlorobium tepidum and the green non-sulfur bacterium Chloroflexus aurantiacus. Arch. Microbiol. 170: 285-296.

Gupta, R.S. 2000. The phylogeny of proteobacteria: Relationships to other eubacterial phyla and eukaryotes. FEMS Microbiol. Rev. 24: $367-402$.
Haas, E.S., Brown, J.W., Pitulle, C., and Pace, N.R. 1994. Further perspective on the catalytic core and secondary structure of ribonuclease P RNA. Proc. Natl. Acad. Sci. 29: 2527-2531.

Hartmann, E. and Hartmann, R.K. 2003. The enigma of Ribonuclease $\mathrm{P}$ evolution. Trends Genet. 19: 561-569.

Heide, C., Pfeiffer, T., Nolan, J.M., and Hartmann, R.K. 1999. Guanosine 2-NH2 groups of Escherichia coli RNase P RNA involved in intramolecular tertiary contacts and direct interactions with tRNA. RNA 5: 102-116.

Hofacker, I.L. 2003. Vienna RNA secondary structure server. Nucleic Acids Res. 31: 3429-3431.

Huber, R., Wilharm, T., Huber, D., Trincone, A., Burggraf, S., König, H., Rachel, R., Rockinger, I., Fricke, H., and Stetter, K.O. 1992. Aquifex pyrophilus gen. nov. sp. nov., represents a novel group of marine hyperthermophilic hydrogen-oxidizing bacteria. Syst. Appl. Microbiol. 15: 340-351.

Kazantsev, A.V., Krivenko, A.A., Harrington, D.J., Carter, R.J., Holbrook, S.R., Adams, P.D., and Pace, N.R. 2003. High-resolution structure of RNase P protein from Thermotoga maritima. Proc. Natl. Acad. Sci. 100: 7497-7502.

Klenk, H.P., Meier, T.D., Durovic, P., Schwass, V., Lottspeich, F., Dennis, P.P., and Zillig, W. 1999. RNA polymerase of Aquifex pyrophilus: Implications for the evolution of the bacterial rpoBC operon and extremely thermophilic bacteria. J. Mol. Evol 48: 528-541.

Leontis, N.B. and Westhof, E. 1998. A common motif organizes the structure of multi-helix loops in $16 \mathrm{~S}$ and $23 \mathrm{~S}$ ribosomal RNAs. J. Mol. Biol. 283: 571-583.

Lück, R., Gräf, S., and Steger, G. 1999. ConStruct: A tool for thermodynamic controlled prediction of conserved secondary structure. Nucleic Acids Res. 27: 4208-4217.

Massire, C., Jaeger, L., and Westhof, E. 1998. Derivation of the three-dimensional architecture of bacterial ribonuclease P RNAs from comparative sequence analysis. J. Mol. Biol. 279: 773-793.

O'Donnell, S.M. and Janssen, G.R. 2001. The initiation codon affects ribosome binding and translational efficiency in Escherichia coli of cI mRNA with or without the $5^{\prime}$ untranslated leader. J. Bacteriol. 183: $1277-1283$.

Olsen, G.J., Matsuda, H., Hagstrom, R., and Overbeek, R. 1994. fastDNAml: A tool for construction of phylogenetic trees of DNA sequences using maximum likelihood. Comput. Appl. Biosci. 10: 41-48.

Rivera-León, R., Green, C.J., and Vold, B.S. 1995. High-level expression of soluble recombinant RNase P protein from Escherichia coli. J. Bacteriol. 177: 2564-2566.

Smith, D., Burgin, A.B., Haas, E.S., and Pace, N.R. 1992. Influence of metal ions on the ribonuclease P reaction. Distinguishing substrate binding from catalysis. J. Biol. Chem. 267: 2429-2436.

Swanson, R.V. 2001. Genome of Aquifex aeolicus. Methods Enzymol. 330: $158-169$.

Torres-Larios, A., Swinger, K.K., Krasilnikov, A.S., Pan, T., and Mondragon, A. 2005. Crystal structure of the RNA component of bacterial ribonuclease P. Nature 437: 584-587.

Tsai, H.Y., Masquida, B., Biswas, R., Westhof, E., and Gopalan, V. 2003. Molecular modeling of the three-dimensional structure of the bacterial RNase P holoenzyme. J. Mol. Biol. 325: 661-675.

Willkomm, D.K., Feltens, R., and Hartmann, R.K. 2002. tRNA maturation in Aquifex aeolicus. Biochimie 84: 713-722.

Willkomm, D.K., Minnerup, J., Hüttenhofer, A., and Hartmann, R.K. 2005. Experimental RNomics in Aquifex aeolicus: Identification of small non-coding RNAs and the putative 6S RNA homolog. Nucleic Acids Res. 33: 1949-1960.

Wegscheid, B., Condon, C., and Hartmann, R.K. 2006. Type A and B RNase P RNAs are interchangeable in vivo despite substantial biophysical differences. EMBO Rep. 7: 411-417.

Zhong, X., Leontis, N., Qian, S., Itaya, A., Qi, Y., Boris-Lawrie, K., and Ding, B. 2006. Tertiary structural and functional analyses of a viroid RNA motif by isostericity matrix and mutagenesis reveal its essential role in replication. J. Virol. 80: 8566-8581.

Zuker, M. 2003. Mfold web server for nucleic acid folding and hybridization prediction. Nucleic Acids Res. 31: 3406-3415. 

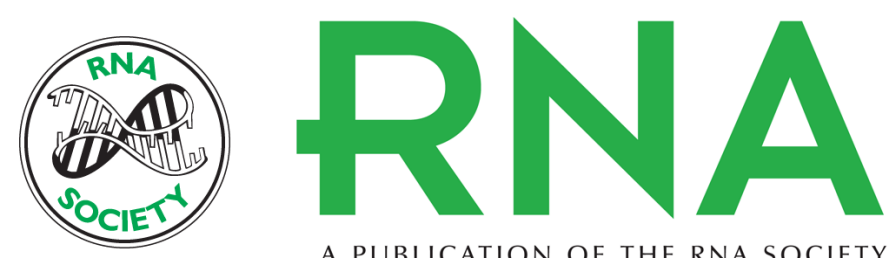

A PUBLICATION OF THE RNA SOCIETY

\section{Thermostable RNase P RNAs lacking P18 identified in the Aquificales}

Michal Marszalkowski, Jan-Hendrik Teune, Gerhard Steger, et al.

RNA 2006 12: 1915-1921 originally published online September 27, 2006

Access the most recent version at doi:10.1261/rna.242806

\section{References}

This article cites 38 articles, 7 of which can be accessed free at:

http://rnajournal.cshlp.org/content/12/11/1915.full.html\#ref-list-1

License

Email Alerting

Receive free email alerts when new articles cite this article - sign up in the box at the Service

top right corner of the article or click here. 